\title{
Poultry Manure-Derived Biochar As A Soil Amendment and Fertilizer for Sandy Soils under Arid Conditions
}

\author{
Wagih Sayed Mohamed* and Amr Ahmad Hammam \\ Soil Department, Faculty of Agriculture, Minia University, El-Minia, Egypt
}

\begin{abstract}
$\mathbf{N}$ ewly reclaimed sandy soils under arid conditions are characterized by poor physical and biochemical properties specially, rapid organic matter decomposition. Field experiment was developed to investigate the feasibility of using poultry manure and its derived biochar integrated with different levels of $\mathrm{N}$ fertilizer as a soil amendment and fertilizer for newly reclaimed sandy soils in Western Desert of El-Minia Governorate, Egypt. Results showed that application of poultry manure (PM) or its derived biochar (PMB) in combination with inorganic $\mathrm{N}$ levels had caused significant changes on a range of the investigated sandy soil biochemical properties including $\mathrm{pH}, \mathrm{EC}$, mineral $\mathrm{N}$, dissolved organic carbon (DOC), dissolved organic $\mathrm{N}$ (DON) and quotient DOC/DON. Overall, the impact of PMB on soil physical properties was detected to be superior than the impact of PM, regardless the inorganic $\mathrm{N}$ levels. In addition, the obtained results showed that poultry manure (PM) and its derived biochar (PMB) application had the capacity to stimulate vigorous growth and production levels of wheat (Triticum aestivum L.) and forage sorghum (Sorghum bicolor L.), and to increase soil organic matter content and $\mathrm{N}$-uptake and recovery compared to control. The interesting feature of this research is that PMD increased treated sandy soil organic carbon (SOC) 1.75 times more than soil treated with PM itself at the end of cropping seasons. It could be concluded that biochar derived from organic wastes considers as a source of stabile carbon and could be very hopeful choice for substituting easily decomposable organic manures under arid conditions.
\end{abstract}

Key words: Sandy soil; Poultry; Biochar; Dissolved organic carbon; N-uptake

\section{Introduction}

Animal organic wastes application to soils was always an important practice in agricultural lands across the world. It was stated that animal manures improve soil physical, chemical and biological properties and provide crops with nutrients. Applying poultry manure directly on soil may result in some environmental fears such as pathogenic bacteria, leaching nitrogen and scarce contribution to stable soil organic carbon (Inal et al. 2015). Also, organic materials i.e. crop residues, farmyard manure and poultry manure are shortly broken down in soil particularly under arid conditions (Arif et al. 2016). In this context, agricultural researchers are always seeking the best alternative for organic amendments such as farmyard and poultry manure.
Biochar derived from poultry manure considered as a good alternative soil amendment (Pituello et al. 2014; Inal et al. 2015). The organic wastes consist of a labile carbon, however, biochar obtained from organic wastes considers as a source of stabile carbon (Joseph et al. 2010; Agyarko-Mintah et al. 2017).

Lehmann and Joseph (2009) presented that biochar can be defined as a carbon rich product when biomass such as woods, manures or leaves is heated in a closed container with little or unavailable oxygen. In previous studies, effect of wide range of pyrolysis temperature on biochar characteristics has been investigated, starting from $200^{\circ} \mathrm{C}$ up to $1000^{\circ} \mathrm{C}$ (Verheijen et al., 2010; Zhang et al., 2015; Suliman et al., 2016; Mandal et al. 
2018; Sikder and Joardar, 2018). Biochar has many possible benefits, improves moisture retention which may reduce the demand for irrigation and make cropping more secure, boosts plant growth, increase and sustain crop yields, also help improve problematic nutrient-poor soils (Barrow 2012). One of the most important biochar benefits is encouraging carbon sequestration (Zhang et al., 2019). Biochar, in last 10 years, has been wildly investigated for agricultural purposes in sandy soils under arid conditions by ways of considering it as a soil amendment, improving soil physical, chemical and biological properties (Al-Wabel et al. 2017; Abdelraouf et al. 2017; Ali 2018).

Gathorne-Hardy et al. (2009) presented that the application of biochar with $\mathrm{N}$ fertilizer on a light soil within temperate climate increased spring barley yield by $30 \%$ compared to individual $\mathrm{N}$ fertilizer. Biochar application at a rate of $25 \mathrm{t}$ $\mathrm{ha}^{-1}$ and $50 \mathrm{t} \mathrm{ha}^{-1}$ in combination with urea (75 and $150 \mathrm{~kg} \mathrm{ha}^{-1}$ ) to calcareous soil under semi-arid conditions in a field experiment in Pakistan made a significant improvement in soil quality and maize yield (Arif et al. 2016). Moreover, mineral $\mathrm{N}$ remained at the same concentration from first to second season regardless the rate of applied $\mathrm{N}$ fertilizer. In a greenhouse experiment, the obtained results by Inal et al. (2015) concluded that applying biochar derived from poultry manure or poultry manure resulted in improvement of chemical properties of calcareous soil and increased $\mathrm{N}$ concentration of both maize and bean plants. Also, $\mathrm{N}$ concentration of lettuce plants was increased following biochar and poultry manure applications (Gunes et al. 2014). Experiments with barley grown on a Nitisol in the highlands of Ethiopia showed that application of biochar obtained from acacia, compost and their mixture resulted in high uptake, agronomic and apparent recovery efficiency of applied $\mathrm{N}$ at similar $\mathrm{N}$ fertilizer rates (Agegnehu et al. 2016).

Egypt has a problem with land resources and there is a continuous demand for expanding agricultural areas to feed ever-increasing population. Most of the available area for expanding agricultural activities are sandy soils characterized by poor physical and chemical properties and located in Egyptian western desert (Ali 2018). Rapid soil organic carbon depletion and low $\mathrm{N}$ use efficiency are main constraints for crop production in these newly reclaimed sandy soils. Addition of high amounts of $\mathrm{N}$ fertilizers is a key factor of crop productivity but
$\mathrm{N}$ in these soils is subject to be lost either by leaching or volatilization. Therefore, applying organic amendments is crucial to develop soil physical properties and consequently enhance $\mathrm{N}$ use efficiency and lessen organic carbon decomposition.

Nitrogen is one of the major essential nutrients for plants, important component of protein and almost all the indispensable processes in plants are associated with the latter (Leghari et al. 2016). Moreover, nitrogen plays a vital role in root growth stimulation, improve fruit quality and increase protein content of fodder crops (Leghari et al. 2016). It was reported that about $50-70 \%$ of applied $\mathrm{N}$ fertilizer subject to loss either directly through different ways, volatilization, leaching and denitrification or indirectly via microbial activities (Deressa et al. 2012; Mandal et al. 2018). Applying biochar derived from manures to sandy soils as a strategy for increasing nutrient use efficiency and decreasing carbon and nitrogen loss under arid and semiarid conditions needs further more studies. Thus, biochar derived from organic wastes could be very hopeful choice for substituting easily decomposable organic manures (Lehmann et al. 2003; Abdelraouf et al. 2017). Few studies have been conducted to investigate the comparison between the effect of poultry manure and its pyrolyzed product (biochar) on some soil physicochemical properties, soil nitrogen and carbon status and productivity of wheat and forage sorghum grown on newly reclaimed sandy soils located in the Egyptian Western Desert.

Thus, the objectives of this study were to explore the possibility of using poultry manurederived biochar (PMB) compared to poultry manure (PM) with different proportions of $\mathrm{N}$ fertilizer as a soil amendment for newly reclaimed sandy soils in a field experiment on Western Desert of Egypt.

\section{Materials and methods}

\section{Experimental site}

This study was conducted in two successive cropping seasons of 2015 and 2016 on a special farmer's field at El-Minia Governorate in the Western Desert of Egypt. The area under investigation lies in arid region $\left(28^{\circ} 18^{\prime} 16^{\prime \prime} \mathrm{N}\right.$, $30^{\circ} 34^{\prime} 38^{\prime}$ 'E) characterized with an evaporation rate of $4897.91 \mathrm{~mm} /$ year, annual rainfall ranges from $23-33 \mathrm{~mm} /$ year and the temperatures in winter varied from 5 to $20{ }^{\circ} \mathrm{C}$ with maximum temperature $42{ }^{\circ} \mathrm{C}$ in July according to data from 
Egyptian Meteorological Agency. The soil of the experimental site has a sand texture, $\mathrm{pH} 8.18$, with an electrical conductivity $0.85 \mathrm{dSm}^{-1}$ and soil organic carbon (SOC) $0.19 \%$. The physical and chemical properties of the studied soil are presented in Table 1. Air-dried samples of $\mathrm{PM}$ and PMB $(<2 \mathrm{~mm})$ were divided into two proportions. Analyses such as $\mathrm{BD}, \mathrm{pH}, \mathrm{EC}, \mathrm{OC}$ and $\mathrm{CEC}$ were undertaken in the first proportion as described later for soil analyses. The second proportion was oven dried at $65^{\circ} \mathrm{C}$ and digested using $\mathrm{H}_{2} \mathrm{SO}_{4}$ and $\mathrm{H}_{2} \mathrm{O}_{2}$ and analyzed according to the procedures described by Page et al.(1982); Avery and Bascombe (1982) to determine N content and available $\mathrm{P}$ and $\mathrm{K}$. Characteristics of $\mathrm{PM}$ and PMB are shown in Table 1.

Poultry manure (PM) and poultry manure-derived biochar $(P M B)$ preparation

Air-dried stalk bases of date palm trees were sliced and crashed and then used as bedding material for poultry farming for 50 days in deep litter system. The bedding material was collected and stacked on the cropland to dry before its application as a poultry manure to the soil. The air-dried poultry manure was used as a feedstock for biochar production. The pyrolysis of PM was undertaken in a muffle furnace under limited supply of oxygen at $300{ }^{\circ} \mathrm{C}$ for 2 hours. The production yield of poultry manure-derived biochar (PMB) was approximately $50 \%$ of the feedstock, namely 10 tons of biochar made out of 20 tons of poultry manure. Finally, PMB was crashed and sieved through a 2-mm sieve before its application as a soil amendment.

\section{Experimental design}

The field experiment layout included two organic amendments (PM and PMB) applied at the rates of 20 and $10 \mathrm{t} \mathrm{h}^{-1}$ respectively in combination with 5 levels of inorganic nitrogen fertilizer $(0$, $25,50,75$ and $100 \%$ of the recommended dose) with a treatment $(100 \%$ of the recommended dose of $\mathrm{N}$ alone) and a control treatment (no PM, PMB or $\mathrm{N}$ fertilizer). The organic amendments were incorporated into the top $20 \mathrm{~cm}$ of the studied soil ten days before the beginning of cropping cycle (wheat - forage sorghum). The field experiment was started on November $15^{\text {th }}, 2015$ with sowing wheat at a rate of $190 \mathrm{~kg}$ seeds ha-1 and followed by sowing forage sorghum at a rate of $75 \mathrm{~kg}$ seeds $\mathrm{ha}^{-1}$. The experimental unit was a plot of $3.5 \mathrm{~m}$ $\times 3 \mathrm{~m}$ in size, with 3 replicates in a complete randomized block design for each treatment. The recommended doses of NPK were respectively $285 \mathrm{~kg} \mathrm{~N} \mathrm{ha}^{-1}, 74 \mathrm{~kg} \mathrm{P}_{2} \mathrm{O}_{5} \mathrm{ha}^{-1}$ and $57 \mathrm{~kg} \mathrm{~K}_{2} \mathrm{O}$ $\mathrm{ha}^{-1}$ for wheat and $238 \mathrm{~kg} \mathrm{~N} \mathrm{ha}^{-1}, 71.5 \mathrm{~kg} \mathrm{P}_{2} \mathrm{O}_{5}$ $\mathrm{ha}^{-1}$ and $120 \mathrm{~kg} \mathrm{~K}_{2} \mathrm{O} \mathrm{ha}{ }^{-1}$ for forage sorghum as recommended by the Ministry of Agriculture, Egypt. The used NPK commercial fertilizers were ammonium sulphates $(20 \% \mathrm{~N})$, superphosphate $\left(15.5 \% \quad \mathrm{P}_{2} \mathrm{O}_{5}\right)$ and potassium sulphates $(48 \%$ $\mathrm{K}_{2} \mathrm{O}$ ). The sprinkler irrigation system was used and treatments layouts are shown in Table 2.

TABLE 1. Physicochemical characteristics of soil, poultry manure (PM) and poultry manure-derived biochar (PMB)

\begin{tabular}{lccc}
\hline Property & Soil & Poultry manure (PM) & $\begin{array}{c}\text { Poultry manure-derived biochar } \\
\text { (PMB) }\end{array}$ \\
\hline Sand (\%) & 89.7 & - & - \\
Silt (\%) & 5.6 & - & - \\
Clay (\%) & 4.7 & - & - \\
Texture class & Sand & - & 6.9 \\
pH & 8.18 & 5.62 & 2.17 \\
EC $\left(\mathrm{dSm}{ }^{-1}\right)$ & 0.85 & 1.73 & 17.64 \\
OC $(\%)$ & 0.19 & 35.28 & 1.55 \\
Total $-\mathrm{N}(\%)$ & 0.02 & 1.97 & 11.38 \\
C/N & 9.50 & 17.91 & 45.71 \\
CEC $\left(\mathrm{cmol}_{\mathrm{c}} \mathrm{kg}^{-1}\right)$ & 3.46 & 38.26 & 0.25 \\
Bulk Density $\left(\mathrm{g} \mathrm{cm}^{-3}\right)$ & 1.59 & 0.53 & - \\
ava. P $\left(\mathrm{mg} \mathrm{kg}^{-1}\right)$ & 4.5 & - & - \\
ava. K $\left(\mathrm{mg} \mathrm{kg}^{-1}\right)$ & 65 & - & 1.72 \\
P (\%) & - & 1.12 & 1.95 \\
K (\%) & - & 1.34 & \\
\hline
\end{tabular}


TABLE 2. Layouts and abbreviations of the studied treatments

\begin{tabular}{cccl}
\hline PM $\left(\mathbf{M g ~ h} \mathbf{~}^{-1}\right)$ & PMB $\left(\mathbf{M g ~ h}^{-1}\right)$ & N levels & Abbreviation \\
\hline 0 & 0 & 0 & Control \\
0 & 0 & $100 \%$ & $100 \% \mathrm{~N}$ \\
20 & 0 & 0 & $\mathrm{PM}+0 \% \mathrm{~N}$ \\
0 & 10 & 0 & $\mathrm{PMB}+0 \% \mathrm{~N}$ \\
20 & 0 & $25 \%$ & $\mathrm{PM}+25 \% \mathrm{~N}$ \\
0 & 10 & $25 \%$ & $\mathrm{PMB}+25 \% \mathrm{~N}$ \\
20 & 0 & $50 \%$ & $\mathrm{PM}+50 \% \mathrm{~N}$ \\
0 & 10 & $50 \%$ & $\mathrm{PMB}+50 \% \mathrm{~N}$ \\
20 & 0 & $75 \%$ & $\mathrm{PM}+75 \% \mathrm{~N}$ \\
0 & 10 & $75 \%$ & $\mathrm{PMB}+75 \% \mathrm{~N}$ \\
20 & 0 & $100 \%$ & $\mathrm{PM}+100 \% \mathrm{~N}$ \\
0 & 10 & $100 \%$ & $\mathrm{PMB}+100 \% \mathrm{~N}$ \\
\hline
\end{tabular}

\section{Soil and organic amendments analyses}

Undisturbed and disturbed soil surface samples were collected from each plot by the end of cropping cycle (wheat - forage sorghum) to study treatment effects on soil physical and chemical properties. The samples were packed, transported to the laboratory, air dried and sieved through a 2-mm sieve before soil analyses. Undisturbed soil samples were collected using core method to determine bulk density, water holding capacity and field capacity (Blake and Hartge 1986). The porosity was calculated using soil particle density of $2.65 \mathrm{~g} \mathrm{~cm}^{-3}$. Particle size distribution was determined using the Bouyoucous hydrometer method according to Gee and Bauder (1986). Hydraulic conductivity $(\mathrm{cm} / \mathrm{h})$ was measured in the field using tension infiltrometer according to Reynolds and Elrick (1991). Soil pH and EC were measured in a soil-water extract $(1: 2.5 \mathrm{w}: \mathrm{v})$, however PM and PMB $\mathrm{pH}$ and EC were measured in a water extract $(1: 10 \mathrm{w}: \mathrm{v})$. Chemical analyses such as soil organic carbon (SOC), total nitrogen (TN), cation exchange capacity (CEC), available phosphorous and potassium were determined using standard method according to Avery and Bascombe (1982) and Black et al. 1965. Mineral N was determined by steam distillation (Mulvaney, 1996), dissolved organic carbon (DOC) and dissolved organic nitrogen (DON) were determined according to Smolander and Kitunen (2002).

\section{$\mathrm{N}$-uptake and nitrogen recovery}

At physiological maturity of wheat and 3 cuts from forage sorghum plantsin an area of $2 \mathrm{~m}^{2}$ in the center of each plot were harvested to determine grain and straw yields of wheat, fresh and dry weights of forage sorghum. All obtained data were converted into $\mathrm{kg}$ per hectare. The plant samples were washed and oven-dried at $65{ }^{\circ} \mathrm{C}$ to measure dry weight, then ground to pass through a $0.25 \mathrm{~mm}$ sieve. Plant samples were analysed for $\mathrm{N}$ contents according to the procedures described by Page et al. (1982) and Avery and Bascombe, (1982). Nitrogen uptake was calculated for each treatment from dry matter and the corresponding nitrogen contents. Nitrogen recovery $(\mathrm{NR} \%)$ was calculated as the percent of $\mathrm{N}$ applied for each treatment, where: $\mathrm{NR} \%=[($ Plant $\mathrm{N}$-uptake for each treatment $(\mathrm{kg}$ $\left.\mathrm{h}^{-1}\right)$ - Plant N-uptake for control $\left.\left(\mathrm{kg} \mathrm{h}^{-1}\right)\right)$ / Total N applied for each treatment $\left.\left(\mathrm{kg} \mathrm{h}^{-1}\right)\right] \times 100$.

\section{Statistical analysis}

The experimental design was a randomized complete block with three replicates and all data were subjected to variance analysis test and differences among means evaluated using the Least Significant Differences (LSD) methods according to Gomez and Gomez (1984).

\section{$\underline{\text { Results and Discussion }}$}

Effect of treatments on some soil physical and hydro-physical properties

Organic manures and its derived biochar have been widely used to alleviate some poor sandy soil physical and hydro-physical properties such as low water retention, soil moisture, porosity and ineffective water use productivity especially in newly reclaimed sandy soils in Egypt. The effects of PM and its biochar (PMB) in combination with inorganic $\mathrm{N}$ levels on a range of soil physical 
properties including BD, porosity, WHC, FC and $\mathrm{HC}$ are presented in Table 3. Data presented in Table 3 showed that both poultry manure (PM) and its derived biochar (PMB) had significant influences upon bulk density (BD), porosity, water holding capacity (WHC), field capacity (FC) and hydraulic conductivity (HC). Generally, the addition of $\mathrm{PM}$ and $\mathrm{PMB}$ respectively at a rate of 20 and $10 \mathrm{t} \mathrm{ha}^{-1}$ to the investigated sandy soil significantly caused improvement in soil physical properties regardless the inorganic $\mathrm{N}$ levels.

Overall, the impact of PMB on soil physical and chemical properties was detected to be superior than the impact of PM albeit double applied amounts of poultry manure. Three plausible explanations for the superiority effect of manure-derived biochar (PMB) over poultry manure (PM) on the investigated soil physical and hydro-physical properties may be due to, 1) direct pore contribution from pores in biochar itself, 2) creation of accommodation pores between biochar and the adjacent soil, and 3) improving the persistence of soil pores due to stabile organic carbon in biochar compared to poultry manure (Hardie et al. 2014). Biochar is highly porous, therefore its application to sandy soil is considered to improve various soil physical properties such as bulk density, porosity, water retention and hydraulic conductivity (Major et al. 2009; Verheijen et al. 2010).
The obtained data showed that soil BD significantly reduced in PM and PMB treatments by 9.14 and $17.35 \%$ over the control or $100 \%$ $\mathrm{N}$ treatments. On opposite tendency, porosity increased by an average of $13.75 \%$ and $26.25 \%$ as a result of applying PM and PMB to the soil, respectively. Also, PM and PMB significantly increased $\mathrm{WHC}$ as soil porosity changed and recorded a relative increase by $30.27 \%$ for $\mathrm{PM}$ and $60.61 \%$ for PMB. In addition, compared to soil untreated with PM and PMB, FC of the soil amended with PM and PMB increased respectively by 20.72 and $30.82 \%$. Regarding hydraulic conductivity (HC), treating such sandy soil characterized by high $\mathrm{HC}$ with PM and PMB resulted in a significant decrease in $\mathrm{HC}$. The obtained results showed that HC decreased by 9.43 and $11.84 \%$ in plots treated with PM and $\mathrm{PMB}$, respectively. Previous studies also reinforce our obtained results (Revell et al., 2012).

Efficient management of soil moisture movement and retention is important issue for agricultural production in newly reclaimed sandy soils in view of water shortage and water loss under arid conditions. The effect of animal manures such as PM on soil physical properties has been widely studied. The addition of PM to soil enhanced soil organic matter, improved soil structure, bulk density, porosity, water holding capacity and hydraulic conductivity (Ojeniyi et al. 2013; Agbede et al. 2017). Results of this

TABLE 3. Effects of PM, PMB integrated with inorganic $N$ fertilizer on soil physical and hydro-physical properties

\begin{tabular}{lccccc}
\hline Treatments & $\begin{array}{c}\text { BD } \\
\mathbf{g} \mathbf{~ c m}^{-3}\end{array}$ & $\begin{array}{c}\text { Porosity } \\
\mathbf{m}^{\mathbf{3}} \mathbf{m}^{-3}\end{array}$ & $\begin{array}{c}\mathbf{W H C} \\
\mathbf{\%}\end{array}$ & $\begin{array}{c}\text { FC } \\
\mathbf{\%}\end{array}$ & $\begin{array}{c}\text { HC } \\
\text { cm/hour }\end{array}$ \\
\hline Control & 1.58 & 0.40 & 21.32 & 10.45 & 42.6 \\
$100 \% \mathrm{~N}$ & 1.59 & 0.40 & 21.16 & 10.21 & 42.2 \\
$\mathrm{PM}+0 \% \mathrm{~N}$ & 1.42 & 0.46 & 28.39 & 12.62 & 38.7 \\
$\mathrm{PMB}+0 \% \mathrm{~N}$ & 1.33 & 0.50 & 33.30 & 13.28 & 37.5 \\
$\mathrm{PM}+25 \% \mathrm{~N}$ & 1.45 & 0.45 & 27.03 & 12.82 & 38.1 \\
$\mathrm{PMB}+25 \% \mathrm{~N}$ & 1.31 & 0.51 & 34.93 & 13.55 & 37.3 \\
$\mathrm{PM}+50 \% \mathrm{~N}$ & 1.43 & 0.46 & 28.17 & 12.59 & 38.6 \\
$\mathrm{PMB}+50 \% \mathrm{~N}$ & 1.29 & 0.51 & 34.53 & 13.38 & 37.4 \\
$\mathrm{PM}+75 \% \mathrm{~N}$ & 1.44 & 0.46 & 27.94 & 12.27 & 38.4 \\
$\mathrm{PMB}+75 \% \mathrm{~N}$ & 1.30 & 0.51 & 33.93 & 13.85 & 37.2 \\
$\mathrm{PM}+100 \% \mathrm{~N}$ & 1.46 & 0.45 & 26.82 & 12.05 & 38.2 \\
$\mathrm{PMB}+100 \% \mathrm{~N}$ & 1.32 & 0.50 & 33.88 & 13.51 & 37.5 \\
\hline
\end{tabular}

BD: Bulk density, WHC: Water holding capacity, FC: Field capacity, HC: Hydraulic conductivity 
research revealed that poultry manure and its derived biochar addition induced pronounced effect on soil moisture content at saturation point (WHC), field capacity (FC) and consequently available water. Improvements in soil moisture constants could be due to increasing water holding pores and decreasing water loss by leaching and deep percolation after organic matter addition. Also, the higher values of soil porosity and lower values of bulk density for treated soils due to organic matter addition might induced higher soil capacity to absorb water and retain more water content (Aslam et al. 2014; Ali 2018).

\section{Effect of treatments on soil chemical properties}

Data presented in Table 4 showed that application of both poultry manure (PM) and its derived biochar (PMB) in combination with inorganic $\mathrm{N}$ levels had caused significant changes on a range of the investigated sandy soil chemical properties including $\mathrm{pH}, \mathrm{EC}$, mineral $\mathrm{N}$, dissolved organic carbon (DOC), dissolved organic $\mathrm{N}$ (DON) and quotient DOC/DON. Results indicated that sandy soil investigated was alkaline in soil reaction with safe limit of electrical conductivity.
After soil treatment with poultry manure (PM) and its derived biochar (PMB), there was a decreasing tendency in soil $\mathrm{pH}$ in plots treated with $\mathrm{PM}$ followed by PMB due to $\mathrm{pH}$ of PM and PMB used in this study was 5.62 and 6.9 , nevertheless such a significant decrease was not detected (Table 4). It is obviously that added amounts of PM and PMB were not enough to decrease soil $\mathrm{pH}$ significantly by the end of cropping season. The application of PM and PMB caused significant increases in EC of treated soil plots compared to untreated. This increase in soil EC obviously associated with the higher EC values of PM and PMB (1.73 and $\left.2.17 \mathrm{dSm}^{-1}\right)$. Concerning the integration between organic amendments and inorganic $\mathrm{N}$ levels there was no significant differences in EC values among treatments except for treatments $\mathrm{PM}+75 \% \mathrm{~N}$ and $\mathrm{PM}+100 \% \mathrm{~N}$ compared to $\mathrm{PMB}+50 \% \mathrm{~N}$ and $\mathrm{PMB}+75 \% \mathrm{~N}$. Generally, the EC values in plots either treated with PM alone or in combination with inorganic $\mathrm{N}$ levels were higher than those in plots treated with PMB (Table 4). This clearly attributed to the higher application rate (double rate) of PM yet the higher value of EC for PMB (2.17).

TABLE 4. Effect of PM, PMB and their integration with inorganic $N$ fertilizer on some soil chemical properties

\begin{tabular}{|c|c|c|c|c|c|c|c|}
\hline Treatments & pH & EC & $\begin{array}{l}\text { SOC } \\
\mathrm{g} \mathrm{kg}^{-1}\end{array}$ & $\begin{array}{c}\text { Mineral N } \\
\text { mg kg }^{-1}\end{array}$ & $\begin{array}{c}\text { DOC } \\
\text { mg kg }^{-1}\end{array}$ & $\begin{array}{c}\text { DON } \\
\text { mg kg }^{-1}\end{array}$ & DOC/DON \\
\hline Control & 8.15 & 0.87 & 2.07 & 13 & 28 & 5 & 5.6 \\
\hline $100 \% \mathrm{~N}$ & 8.19 & 0.94 & 2.11 & 39 & 39 & 9 & 4.3 \\
\hline $\mathrm{PM}+0 \% \mathrm{~N}$ & 7.92 & 1.13 & 3.34 & 21 & 110 & 15 & 7.3 \\
\hline $\mathrm{PMB}+0 \% \mathrm{~N}$ & 8.12 & 1.05 & 5.48 & 16 & 57 & 7 & 8.1 \\
\hline $\mathrm{PM}+25 \% \mathrm{~N}$ & 7.98 & 1.15 & 3.16 & 30 & 105 & 16 & 6.6 \\
\hline $\mathrm{PMB}+25 \% \mathrm{~N}$ & 8.05 & 1.11 & 5.26 & 23 & 54 & 8 & 6.8 \\
\hline $\mathrm{PM}+50 \% \mathrm{~N}$ & 7.95 & 1.18 & 3.03 & 32 & 104 & 17 & 6.1 \\
\hline $\mathrm{PMB}+50 \% \mathrm{~N}$ & 8.13 & 1.07 & 5.22 & 25 & 51 & 8 & 6.4 \\
\hline $\mathrm{PM}+75 \% \mathrm{~N}$ & 8.00 & 1.21 & 2.78 & 35 & 101 & 18 & 5.6 \\
\hline $\mathrm{PMB}+75 \% \mathrm{~N}$ & 8.10 & 1.06 & 5.12 & 30 & 48 & 7 & 6.9 \\
\hline $\mathrm{PM}+100 \% \mathrm{~N}$ & 7.95 & 1.22 & 2.74 & 36 & 101 & 18 & 5.6 \\
\hline $\mathrm{PMB}+100 \% \mathrm{~N}$ & 8.08 & 1.10 & 5.08 & 33 & 47 & 8 & 5.9 \\
\hline L.S. $D_{0.05}$ & 0.26 & 0.13 & 0.45 & 3.27 & 4.16 & 1.60 & \\
\hline
\end{tabular}

EC: Electrical conductivity, SOC: Soil organic carbon, DOC: Dissolved organic carbon, DON: Dissolved organic nitrogen 
By the end of cropping cycle, SOC was significantly increased to an average of 3.01\% for plots treated with PM and $5.25 \%$ for those treated with PMB compared to $2.09 \%$ for the control and $100 \%$ inorganic $\mathrm{N}$ treatments (Table 4). Nevertheless, the applied amount of PM was double the applied amount of PMB, the biochar increased SOC of sandy soil 1.75 times more than PM. This could be associated with the high carbon stability of biochar treated soils increasing soil persistence for decomposition in comparison with poultry manure labile carbon. Also, one of the observations from the obtained data was regular decreases in SOC and increases in the $\mathrm{C} / \mathrm{N}$ ratio as the applied amount of inorganic $\mathrm{N}$ fertilizers increased in combination with organic fertilizers. This may be illustrated with mineralization of organic amendments and immobilization of inorganic N. In this context, the obtained results showed that mineral $\mathrm{N}$ of plots treated with PM and PMB progressively increased with the increase in applied amount of inorganic $\mathrm{N}$ (Table 4). Moreover, treatment of $100 \% \mathrm{~N}$ without any organic addition recorded the highest concentration of mineral $\mathrm{N}$.

The nitrogen inputs into the investigated sandy soil through poultry manure (PM) was nearly double $(394 \mathrm{~kg})$ its derived biochar inputs $(155 \mathrm{~kg})$. Whereas, carbon inputs through PM (7060 kg) was much higher (nearly fourfold) than that of the poultry manure biochar (PMB) due to manure double inputs and higher contents of carbon and nitrogen. Thus, always DOC and DON values were higher in all PM treatments than in PMB treatments. By contrast, always the quotient DOC/DON values were higher in all PMB treatments than in PM treatments, reflecting further increase in treated sandy soils $\mathrm{C} / \mathrm{N}$ ratios by biochar addition compared to poultry manure. Organic components such as DOC and DON are considered as labile organic substrates. Thus, the soil contents of DOC and DON are indicators for stability of organic amendments such as PM and PMB. Mean concentrations of DOC ranged from 47 to $110 \mathrm{mg} \mathrm{kg}^{-1}$ and DON from 7 to $18 \mathrm{mg}$ $\mathrm{kg}^{-1}$ indicating considerable differences among treatments (Table 4). Contents of DOC and DON were significantly affected by the application of PM and PMB either alone or with inorganic $\mathrm{N}$ different levels in comparison with control.

The control treatment recorded a ratio of DOC/DON 5.6 and in plots treated with full doses of inorganic $\mathrm{N}$ recorded the lowest ratio
4.3 due to increased levels of inorganic nitrogen. In Egypt, organic manures characterized by labile organic carbon, applied to sandy soils under arid conditions are always subject to high decomposition and mineralization rates through short growing cropping seasons. Therefore, sustainable productivity in sandy soils desires frequently addition of such organic amendments. However, biochar obtained from organic wastes considers as a source of stabile carbon (Joseph et al. 2010; Agyarko-Mintah et al. 2017).

A better understanding of soil organic matter (SOM) dynamics is needed to improve management of soil organic carbon and nitrogen. Dissolved organic carbon, organic carbon that can pass through 0.4-0.6 $\mu \mathrm{m}$ membrane filter (Bolan et al. 2011), usually used to measure the DOM. Dissolved organic carbon characterized by mobility, thus DOC plays a vital role in transporting nutrients (Schmidt et al. 2011; van den Berg et al. 2012). Due to its mobility, DOC plays an important role in transport of nutrients and pollutants such as nitrates and heavy metals. Martin-Olmedo and Rees (1999) reported in a 44-day aerobic incubation experiment that the application of poultry manure to a sandy loam soil resulted in an increase of DOC concentrations. Liu et al. (2016) explored that mixing biochar with pure sand at a rate from 2 to $10 \mathrm{wt} \%$ increased the cumulative loss of DOC compared to untreated sand, however only $0.06-0.18 \%$ of biochar carbon was transported to ground water and streams as DOC for all rates.

Effect of treatmentson wheat and forage sorghum yield and $N$-uptake

The application of PM and PMB without any addition of inorganic $\mathrm{N}$ fertilizer significantly improved the growth of wheat in comparison with control (Table 5). The grain and straw yields were significantly increased by 62.35 and $77.75 \%$ for PM, but increased by 35.66 and $47.84 \%$ for PMB, relatively to control. Addition of inorganic $\mathrm{N}$ fertilizer in combination with both PM and PMB resulted in significant increases of the grain and straw yields. The latter were gradually increased as the amount of inorganic $\mathrm{N}$ fertilizer increased. Comparing between PM and PMB at different levels of inorganic $\mathrm{N}$, the obtained results showed higher relative increases in both grain and straw yields in plots treated with PM than in those treated with PMB (Table 5). The higher yields of grain and straw were recorded with $\mathrm{PM}+100 \% \mathrm{~N}$ treatment. On the other hand, using the full dose 
of inorganic $\mathrm{N}$ without any organic amendments additions and relatively to control recorded increases of grain and straw yields by 133.63 and $123.82 \%$. These increases were achieved in plots treated with PM at $50 \%$ of the full dose of inorganic $\mathrm{N}$ and in plots treated with $\mathrm{PMB}$ at $75 \%$ of the full dose of inorganic $\mathrm{N}$.

Regarding fresh and dry weights of forage sorghum ( 3 cuts), all treatments caused significant increases in fresh and dry weights (Table 5). Relatively to control, the full dose of inorganic $\mathrm{N}$ increased fresh and dry weights of forage sorghum by 24.12 and $22.94 \%$. The fresh weight of sorghum plants respectively increased by $13.35,18.46,30.95,41.23$ and $47.32 \%$ for PM and its combinations with inorganic $\mathrm{N}$ levels, however relevant increases caused by PMB along with inorganic $\mathrm{N}$ levels were 5.11, 16.62, 18.83, 24.86 and $26.46 \%$. On the other hand, the dry weight of sorghum plants respectively increased by $15.65,22.15,32.23,42.44,50.80 \%$ for PM and its combinations with inorganic $\mathrm{N}$ levels, however relevant increases caused by PMB along with inorganic $\mathrm{N}$ levels were 8.36, 15.38, 19.89, 36.87 and $41.11 \%$. The statistical analysis showed no significant differences among means of forage sorghum dry weight for treatments $\mathrm{PM}+75 \% \mathrm{~N}$, $\mathrm{PMB}+75 \% \mathrm{~N}, \mathrm{PM}+100 \% \mathrm{~N}$ and $\mathrm{PMB}+100 \% \mathrm{~N}$.
The increase in yields of both crops over the control as a result of direct and residual effects of inorganic $\mathrm{N}$ may be due to higher $\mathrm{N}$ availability at vital growth periods, more biosynthesis of carbohydrates and their translocation. It is noticed that the increase in yield as a result of integration between either PM or PMB and inorganic $\mathrm{N}$ was more at the higher $\mathrm{N}$ levels and less at the lower ones. This might be attributed to the fact that the higher levels of inorganic $\mathrm{N}$ rush the mineralization of organic $\mathrm{N}$ which reflected on yield. Biochar application in combination with urea (75 and $150 \mathrm{~kg} \mathrm{ha}^{-1}$ ) to calcareous soil under semi-arid conditions in a field experiment in Pakistan made a significant improvement in soil quality and maize yield. Gathorne-Hardy et al. (2009) reported that the application of biochar with $\mathrm{N}$ fertilizer on a sandy soil increased spring barley yield by $30 \%$ compared to individual $\mathrm{N}$ fertilizer. Also, obtained results by Sikder and Joardar (2018) stated that application of derivedpoultry manure biochar improved plant growth and biomass production.

Application of PM, PMB and their integration with different inorganic $\mathrm{N}$ levels significantly increased $\mathrm{N}$-uptake by wheat and forage sorghum plants in comparison with control treatments (Figure 1, 2). Soil plots treated with PM alone

TABLE 5. Effect of PM, PMB integrated with inorganic $N$ fertilizer on wheat and forage sorghum yield

\begin{tabular}{|c|c|c|c|c|}
\hline \multirow[b]{2}{*}{ Treatments } & \multicolumn{2}{|c|}{ Wheat } & \multicolumn{2}{|c|}{ Forage sorghum } \\
\hline & $\begin{array}{c}\text { Grain yield, } \\
\text { kg h}^{-1}\end{array}$ & $\begin{array}{c}\text { Straw yield, } \\
\mathrm{kg} \mathrm{h}^{-1}\end{array}$ & $\begin{array}{c}\text { Fresh weight, } \\
\qquad \mathbf{k g ~ h}^{-1}\end{array}$ & $\begin{array}{l}\text { Dry weight, } \\
\text { kg h}^{-1}\end{array}$ \\
\hline Control & 1123.72 & 1313.62 & 36175 & 6940 \\
\hline $100 \% \mathrm{~N}$ & 2625.38 & 2940.43 & 48005 & 9270 \\
\hline $\mathrm{PM}+0 \% \mathrm{~N}$ & 1824.32 & 2335.13 & 43839 & 8720 \\
\hline $\mathrm{PMB}+0 \% \mathrm{~N}$ & 1524.45 & 1942.15 & 40650 & 8170 \\
\hline $\mathrm{PM}+25 \% \mathrm{~N}$ & 2151.44 & 2745.24 & 45815 & 9210 \\
\hline $\mathrm{PMB}+25 \% \mathrm{~N}$ & 1724.45 & 2264.2 & 45101 & 8700 \\
\hline $\mathrm{PM}+50 \% \mathrm{~N}$ & 2968.82 & 3538.83 & 50646 & 9970 \\
\hline $\mathrm{PMB}+50 \% \mathrm{~N}$ & 2068.37 & 2796.44 & 45958 & 9040 \\
\hline $\mathrm{PM}+75 \% \mathrm{~N}$ & 3445.21 & 3758.72 & 54621 & 10740 \\
\hline $\mathrm{PMB}+75 \% \mathrm{~N}$ & 2589.02 & 3433.04 & 48291 & 10320 \\
\hline $\mathrm{PM}+100 \% \mathrm{~N}$ & 3736.24 & 4115.68 & 56977 & 11270 \\
\hline $\mathrm{PMB}+100 \% \mathrm{~N}$ & 2827.27 & 3780.06 & 48909 & 10640 \\
\hline L.S.D ${ }_{0.05}$ & 303.92 & 542.1 & 4057.33 & 984.89 \\
\hline
\end{tabular}

Egypt. J. Soil. Sci. Vol. 59, No. 1 (2019) 


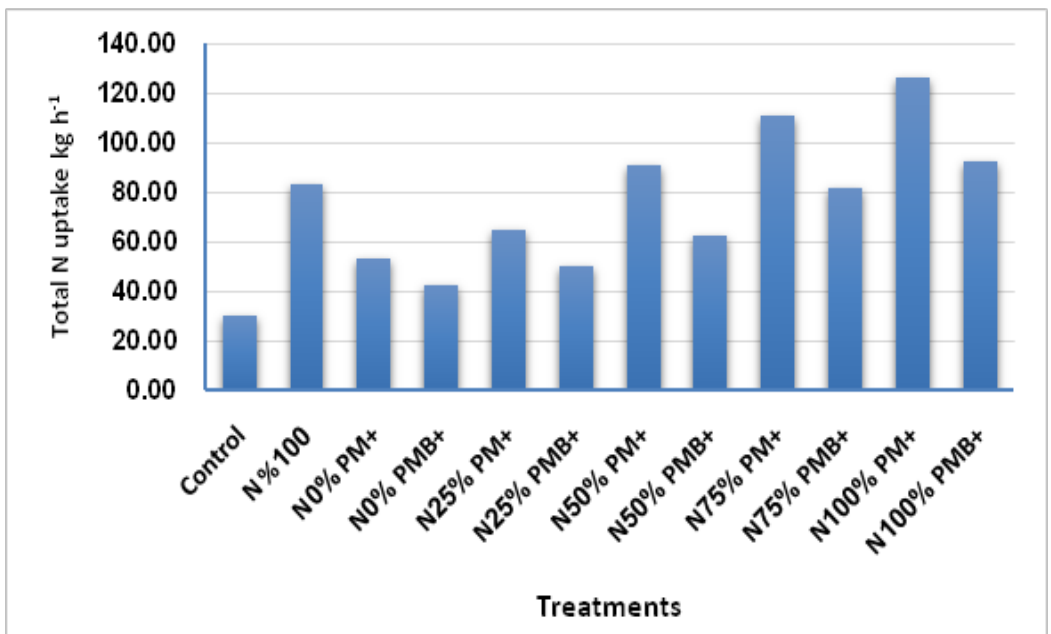

Fig. 1. Effect of PM and PMB integrated with inorganic $N$ fertilizer on total wheat $N$-uptake

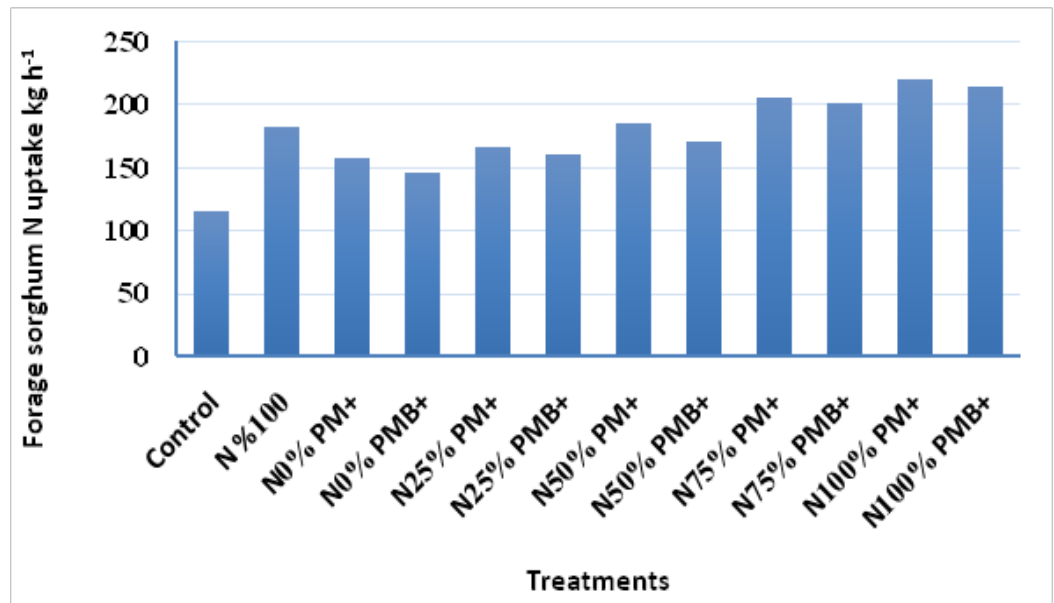

Fig. 2. Effect of $P M$ and $P M B$ integrated with inorganic $N$ fertilizer on forage sorghum $N$-uptake

recorded $53.08 \mathrm{~kg} \mathrm{~h}^{-1}$ total wheat $\mathrm{N}$-uptake compared to $42.48 \mathrm{~kg} \mathrm{~h}^{-1}$ for plots treated with PMB. Considering the levels of inorganic N, the total wheat $\mathrm{N}$-uptake was significantly increased as the applied amount of inorganic $\mathrm{N}$ increased. The obtained data showed that there was no significant difference in $\mathrm{N}$-uptake between plots fertilized by full recommended dose of inorganic $\mathrm{N}\left(83.69 \mathrm{~kg} \mathrm{~h}^{-1}\right)$ and those treated with PM at $50 \%$ of inorganic $\mathrm{N}$ recommended dose $(90.83$ $\mathrm{kg} \mathrm{h} \mathrm{h}^{-1}$ ). However, insignificant difference in N-uptake between plots treated with PMB and those fertilized by full recommended dose of inorganic $\mathrm{N}$ was observed at $75 \%$ of inorganic $\mathrm{N}$ recommended dose $\left(82.16 \mathrm{~kg} \mathrm{~h}^{-1}\right)$.

Total applied $\mathrm{N}\left(\mathrm{kg} \mathrm{h}^{-1}\right)$ to the investigated soil from PM, PMB and inorganic nitrogen fertilizer for each treatment is presented in Table 6. The impact of PMB on nitrogen recovery was detected to be greater than the impact of PM. The obtained data showed that nitrogen recovery significantly reduced in PM and PMB treatments over 100\% $\mathrm{N}$ treatments but significantly increased over the control. Generally, the addition of PM and PMB respectively at a rate of 20 and $10 \mathrm{t} \mathrm{ha}^{-1}$ to the investigated sandy soil caused significant decreases in nitrogen recovery regardless the inorganic $\mathrm{N}$ levels. The obtained results showed almost the same changes in $\mathrm{N}$-uptake by forage sorghum plants. Nevertheless, the difference in N-uptake was insignificant between PM and PMB treatments. Also, there were no significant differences in N-uptake among $\mathrm{PM}+50 \% \mathrm{~N}$, $\mathrm{PMB}+50 \% \mathrm{~N}$ and $100 \% \mathrm{~N}$ treatments. Overall, the superiority of PM in enhancement of $\mathrm{N}$-uptake and yield of both crops may be associated with its large application rate $\left(20 \mathrm{t} \mathrm{h}^{-1}\right)$ and higher content of nitrogen. 
TABLE 6. Total $N$ recovery as applied $N$ from PM, PMB and inorganic nitrogen fertilizer

\begin{tabular}{|c|c|c|c|c|c|c|c|c|c|c|}
\hline \multirow[b]{2}{*}{ Treatments } & \multicolumn{5}{|c|}{ Wheat } & \multicolumn{5}{|c|}{ Forage sorghum } \\
\hline & $\sum$ & $\sum_{E}^{0}$ & 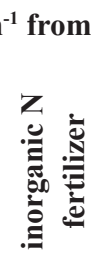 & 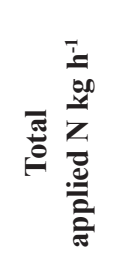 & 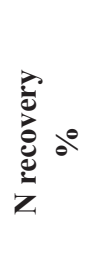 & $\sum$ & $\sum_{i}^{0}$ & 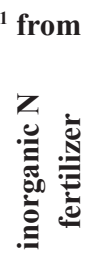 & 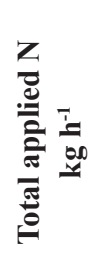 & 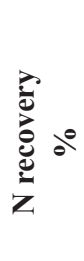 \\
\hline Control & 0 & 0 & 0 & 0 & ------ & 0 & 0 & 0 & 0 & ----- \\
\hline $100 \% \mathrm{~N}$ & 0 & 0 & 285 & 285 & 18.87 & 0 & 0 & 238 & 238 & 27.64 \\
\hline $\mathrm{PM}+0 \% \mathrm{~N}$ & 394 & 0 & 0 & 394 & 5.88 & 394 & 0 & 0 & 394 & 10.64 \\
\hline $\mathrm{PMB}+0 \% \mathrm{~N}$ & 0 & 155 & 0 & 155 & 8.11 & 0 & 155 & 0 & 155 & 19.05 \\
\hline $\mathrm{PM}+25 \% \mathrm{~N}$ & 394 & 0 & 72.25 & 466.25 & 7.55 & 394 & 0 & 59.5 & 453.5 & 11.00 \\
\hline $\mathrm{PMB}+25 \% \mathrm{~N}$ & 0 & 155 & 72.25 & 227.25 & 8.97 & 0 & 155 & 59.5 & 214.5 & 21.00 \\
\hline $\mathrm{PM}+50 \% \mathrm{~N}$ & 394 & 0 & 142.5 & 536.5 & 11.36 & 394 & 0 & 119 & 513 & 13.56 \\
\hline $\mathrm{PMB}+50 \% \mathrm{~N}$ & 0 & 155 & 142.5 & 297.5 & 10.95 & 0 & 155 & 119 & 274 & 20.06 \\
\hline $\mathrm{PM}+75 \% \mathrm{~N}$ & 394 & 0 & 214.75 & 608.75 & 13.30 & 394 & 0 & 178.5 & 572.5 & 15.59 \\
\hline $\mathrm{PMB}+75 \% \mathrm{~N}$ & 0 & 155 & 214.75 & 369.75 & 14.13 & 0 & 155 & 178.5 & 333.5 & 25.59 \\
\hline $\mathrm{PM}+100 \% \mathrm{~N}$ & 394 & 0 & 285 & 679 & 14.24 & 394 & 0 & 238 & 632 & 16.56 \\
\hline $\mathrm{PMB}+100 \% \mathrm{~N}$ & 0 & 155 & 285 & 440 & 14.25 & 0 & 155 & 238 & 393 & 24.93 \\
\hline L.S.D ${ }_{0.05}$ & --- & --- & ---- & --- & 2.47 & --- & -- & --- & -- & 6.88 \\
\hline
\end{tabular}

As the obtained data showed, improvements of soil physical properties, SOC, mineral N, DOC and DON caused by incorporation of PM and PMB into the investigated soil was the main reason behind nutrients availability specially nitrogen and reflected in N-uptake and recovery. Many other investigators inagreement with our results, where applying organic manures such as chicken manure, farmyard and green manures and its derived biochar improved poor physical and chemical properties of sandy soil and increased shoot dry weight of wheat and N-uptake under semi-arid subtropical environment in Pakistan (Elhadi et al. 2015). Addition of poultry manure at a rate of 20 $\mathrm{t} \mathrm{ha}^{-1}$ or its derived biochar at a rate of $10 \mathrm{t} \mathrm{ha}^{-1}$ in combination with inorganic $\mathrm{N}$ to sandy soil under arid conditions made significant changes in the soil $\mathrm{C}: \mathrm{N}$ ratio, either by increasing or decreasing soil nitrogen and carbon contents. Driven by the need for both producing more food and lessening the environmental risks of intensive agriculture in newly reclaimed sandy soils, it could be concluded from these results that reducing soil nitrogen storage and increasing stabile carbon storage by biochar addition is the most feasible approach considering the current soil carbon and nitrogen situation $(\mathrm{C} / \mathrm{N}$ ratio 9.50) in the investigated sandy soils under arid conditions. This will not only reduce the risk of declining carbon stability in these soils caused by the overuse of nitrogen fertilizers, but also will help minimize nitrogen pollution risk and increase crop yield under such conditions.

\section{Profitability analysis}

The economical benefits of wheat and forage sorghum production as affected by PM, PMB application integrated with $\mathrm{N}$ fertilizer levels are shown in Table 7. The total input for each treatment was the sum of PM and PMB price, hectare rent, first and second season costs. However, total output was the totality income from wheat grain, straw and forage sorghum yield. Investment ratio (IR) was calculated from output/input according to Gittinger (1973). The profitability analysis data showed that control treatment recorded IR 0.93, however, $100 \% \mathrm{~N}$ treatment recorded 1.25. Although IR of treatment $\mathrm{PM}+0 \% \mathrm{~N}$ was 1.03 , application of $\mathrm{PMB}$ without inorganic $\mathrm{N}$ fertilizer recorded 0.86 , while application of PM along with 100\% N-level recorded the highest IR 1.35. It was observed that investment ratio was increased due to $\mathrm{N}$ fertilizer levels increase from 0 to $100 \%$. 
TABLE 7. Profitability analysis of wheat and forage sorghum gross production (in LE) as affected by PM, PMB application integrated with $\mathrm{N}$ fertilizer levels

\begin{tabular}{|c|c|c|c|c|c|c|c|}
\hline Treatments & $\begin{array}{c}\text { Total } \\
\text { input } \\
\text { (LE) }\end{array}$ & $\begin{array}{c}\text { Output from } \\
\text { grain }\end{array}$ & $\begin{array}{c}\text { Output from } \\
\text { straw }\end{array}$ & $\begin{array}{c}\text { Sorghum } \\
\text { output }\end{array}$ & $\begin{array}{c}\text { Total } \\
\text { output } \\
\text { (LE) }\end{array}$ & Profits & $\begin{array}{c}\text { IR } \\
\text { Investment } \\
\text { ratio }\end{array}$ \\
\hline Control & 30180 & 4494 & 1970 & 21705 & 28170 & -2009 & 0.93 \\
\hline $100 \% \mathrm{~N}$ & 34940 & 10501 & 4410 & 28803 & 43715 & 8775 & 1.25 \\
\hline $\mathrm{PM}+0 \% \mathrm{~N}$ & 36180 & 7297 & 3502 & 26303 & 37103 & 923 & 1.03 \\
\hline $\mathrm{PMB}+0 \% \mathrm{~N}$ & 39060 & 6097 & 2913 & 24390 & 33401 & -5658 & 0.86 \\
\hline $\mathrm{PM}+25 \% \mathrm{~N}$ & 37370 & 8605 & 4117 & 27489 & 40212 & 2842 & 1.08 \\
\hline $\begin{array}{l}\mathrm{PMB}+25 \% \\
\mathrm{~N}\end{array}$ & 37870 & 6897 & 3396 & 27060 & 37354 & -515 & 0.99 \\
\hline $\mathrm{PM}+50 \% \mathrm{~N}$ & 38560 & 11875 & 5308 & 30387 & 47571 & 9011 & 1.23 \\
\hline $\begin{array}{l}\mathrm{PMB}+50 \% \\
\mathrm{~N}\end{array}$ & 39060 & 8273 & 4194 & 27574 & 40042 & 982 & 1.03 \\
\hline $\mathrm{PM}+75 \% \mathrm{~N}$ & 39750 & 13780 & 5638 & 32772 & 52191 & 12441 & 1.31 \\
\hline $\begin{array}{l}\mathrm{PMB}+75 \% \\
\mathrm{~N}\end{array}$ & 40250 & 10356 & 5149 & 28974 & 44480 & 4230 & 1.11 \\
\hline $\begin{array}{l}\mathrm{PM}+100 \% \\
\mathrm{~N}\end{array}$ & 40940 & 14944 & 6173 & 34186 & 55304 & 14364 & 1.35 \\
\hline $\begin{array}{l}\mathrm{PMB}+100 \% \\
\mathrm{~N}\end{array}$ & 41440 & 11309 & 5670 & 29345 & 46324 & 4884 & 1.12 \\
\hline
\end{tabular}

Although several traditional organic additions have been used to increase sandy soil fertility and crop productivity as such each additive has several drawbacks, viz, poor feasibility in the first year i.e. biochar, unsustainability i.e. organic wastes. Currently, the use of biochar has been considered as an economically feasible and sustainable approach for increasing soil productivity on the long run with its extraordinary of carbon sequestration compared to organic manures (McCarl et al. 2003; Galinato et al. 2011). In addition, huge amounts of organic wastes are pyrolyzed and converted in small, valuable and stable biochar that can be used as a soil amendment and a carbon sequestration means, and this has attracted attention in Egypt as a way to utilize and reduce yearly huge amounts of organic wastes. Furthermore, biochar has been known worldwide as a potentially environmental green candidate for carbon sequestration, but its long-term effects on soil fertility and the mechanism by which it affects soil on the long run have not been yet investigated in Egypt. Biochar application can be economically reasonable if there exists a market recognizes the benefits from avoiding gas emissions and carbon sequestration as a result of biochar application.

Generally, from our point of view in Egypt further research is needed to assess biochar profitability and life cycle for beneficial biocharsandy soil reclamation projects without adverse economic and environmental impacts under arid conditions.Biochar profitability analysis and biochar life cycle based on high loading rates and that are site and climatespecific are necessary before small farmers can use biochar in sandy soil reclamation programs.

\section{Conclusion}

Under this field experiment, poultry manure application at a rate of $20 \mathrm{t} \mathrm{ha}^{-1}$ or its derived biochar at a rate of $10 \mathrm{t} \mathrm{ha}^{-1}$ in combination with inorganic $\mathrm{N}$ to sandy soil under arid conditions made significant improvements in soil physical, hydro-physical, SOC, mineral N, DOC, and DON and consequently reflected on increased wheat and fodder yield compared to individual $\mathrm{N}$ fertilizers. 
Moreover, applying biochar derived from poultry manure or poultry manure resulted in improvement of chemical properties of sandy soil, high uptake, agronomic and apparent recovery efficiency of applied $\mathrm{N}$ for both wheat and sorghum plants. It could be concluded that yearly applying of organic manures consisted of a labile carbon to sandy soils are always subject to high decomposition and mineralization rates, while one addition of its derived biochar considered as a source of stabile carbon through cropping seasons. Therefore, under arid conditions, sustainable productivity in sandy soil reclamation projects desires frequently addition of such organic amendments or one addition of its derived biochar. These results point to the feasibility of using biochar to improve fertility and productivity of sandy soils under arid conditions and emphasize the need to have more studies and focus on biochar life cycle after addition to sandy soils.

\section{References}

Abdelraouf, R. E., Essay, E. F. and Saleh, M. M. S. (2017) Sustainable management of deficit irrigation in sandy soils by producing biochar and adding it as a soil amendment. Middle East J. Agric. Res. 6 (4), 1359-1375.

Agbede, T. M., Adekiya, A. O. and Eifediyi, E. K. (2017) Impact of Poultry Manure and NPK Fertilizer on Soil Physical Properties and Growth and Yield of Carrot. J. Hortic. Res. 25, 81-88.

Agegnehu G, Nelson PN. and Bird, M. I. (2016) The effects of biochar, compost and their mixture and nitrogen fertilizer on yield and nitrogen use efficiency of barley grown on a Nitisol in the highlands of Ethiopia.The Science of the total environment. 569-570, 869-879.

Agyarko-Mintah, E., Cowie, A., Singh, B. P., Joseph, S., Van Zwieten, L., Cowie, A., Harden, S. and Smillie, R. (2017) Biochar increases nitrogen retention and lowers greenhouse gas emissions when added to composting poultry litter. Waste management, 61,138-149.

Ali, M. M. E. (2018) Effect of Plant Residues Derived Biochar on Fertility of a new Reclaimed Sandy Soil and Growth of Wheat (Triticum aestivum L.). Egypt. J. Soil. Sci. 58 (1), 93-103.

Al-Wabel, M. I., Hussain, Q., Usman, A. R. A., Ahmad, M., Abduljabbar, A., Sallam, A. S. and Ok, Y. S. (2018) Impact of biochar properties on soil conditions and agricultural sustainability: A review. Land Degradation \& Development. 29, 2124-2161.
Arif, M., Ali, K., Jan, M. T., Shah, Z., Jones, D. L., Quilliam, R. S. (2016) Integration of biochar with animal manure and nitrogen for improving maize yields and soil properties in calcareous semi-arid agroecosystems. Field Crops Research. 195, 28-35.

Aslam, Z., Khalid, M. and Aon, M. (2014) Impact of Biochar on Soil Physical Properties. Scholarly Journal of Agricultural Science. 4(5), 280-284.

Avery, B. W. and Bascombe, C. L. (1982) Soil survey laboratory methods.Technical Monograph No. 6 Soil Survey of England and Wales, Harpenden.

Barrow, C. J. (2012) Biochar: Potential for countering land degradation and for improving agriculture. Applied Geography. 34, 21-28.

Black, C. A., Evans, D. D., White, J. L., Ensminger, L. E., Clark, F. E. (Eds.). (1965) Methods of Soil Analysis. Am. Soc. of Agron. Inc. Madison, Wisconson, USA, $5^{\text {th }}$ ed, 1979.

Blake, G. R. and Hartge, K. H. (1986) Methods of Soil Analysis.Part 1. Physical and Mineralogical Methods. In: Klute A, Ed, Soil Science Society of America, 2nd Edition, Madison, 363-375.

Bolan, N. S., Adriano, D. C., Kunhikrishnan, A., James, T. K., Mcdowell, R., Senesi, N. (2011) Dissolved Organic Matter: Biogeochemistry, Dynamics, and Environmental Significance in Soils. Advances in Agronomy - ADVAN AGRON. 110, 1-75.

Deressa,H., Dechassa, N. and Ayana, A. (2012) Nitrogen use efficiency of bread wheat: Effects of nitrogen rate and time of application. Journal of soil science and plant nutrition:0-0 doi:10.4067/s071895162012005000002

Elhadi, E. A., Mubarak, A. R., Rezig, F. A. M. (2016) Effects of organic amendments on sand dune fixation. International Journal of Recycling of Organic Waste in Agriculture 5, 1-8.

Galinato, S. P., Yoder, J. K. and Granatstein, D. (2011) "The Economic Value of Biochar in Crop Production and Carbon Sequestration”.Energy Policy 39.

Gathorne-Hardy, A., Knight, J. and Woods, J. (2009) Biochar as a soil amendment positively interacts with nitrogen fertiliser to improve barley yields, in the UK IOP Conference Series: Earth and Environmental Science. 6, 372052.

Gee, G. W. and Bauder, J. W. (1986) Particle Size Analysis. In: Methods of Soil Analysis, Part A. Klute (Ed) 2 ed Vol. 9 nd Am. Soc. Agron. Madison. WI pp: 383-411. 
Gittinger, J. P. (1973) Agriculture project analysis. World Bank Publications, Washington, D.C.

Gomez, K. A., Gomez, A. A. (1984) Statistical procedures for agricultural research $(2$ ed). John wiley and sons, NewYork, 680p.

Gunes, A., Inal, A., Taskin, M. B., Sahin, O., Kaya, E. C., Atakol, A. and Goss, M. (2014) Effect of phosphorus-enriched biochar and poultry manure on growth and mineral composition of lettuce (LactucasativaL. cv.) grown in alkaline soil. Soil Use and Management:n/a-n/a doi:10.1111/ sum.12114.

Hardie, M., Clothier, B., Bound, S., Oliver, G. and Close, D. (2014) Does biochar influence soil physical properties and soil water availability? Plant and Soil. 376, 347-361.

Inal, A., Gunes, A., Sahin, O., Taskin, M. B. and Kaya, E. C. (2015) Impacts of biochar and processed poultry manure, applied to a calcareous soil, on the growth of bean and maize. Soil Use and Management, 31, 106-113.

Joseph, S. D., et al. (2010) An investigation into the reactions of biochar in soil Australian Journal of Soil Research 48, 501.

Leghari, S. J., Wahocho, N. A., Laghari, G. M., Laghari, A. H., Bhabhan, G. M., Talpur, K. H., Bhutto, T. A., Wahocho, S. A. and Lashari, A. A. (2016) Role of Nitrogen for Plant Growth and Development: A review. Advances in Environmental Biolog. 10 (9), 209-218.

Lehmann, J. and Joseph, S. (2009) Biochar for environmental management: An introduction Biochar for Environmental Management: Science and Technology, 1-12.

Lehmann, J., Kern, D. C., Glaser, B. and Woods, W. I. (2003) Amazonian dark earths: origins, properties, management. Dordrecht: Kluwer Academic.10.1007/1-4020-2597-1.

Liu, Z., Dugan, B., Masiello, C. A., Barnes, R. T., Gallagher, M. E. and Gonnermann, H. (2016) Impacts of biochar concentration and particle size on hydraulic conductivity and DOC leaching of biochar-sand mixtures. Journal of Hydrology. 533, 461-472.

Major, J., Steiner, C., Downie, A., Lehmann, J. (2009) Biochar effects on nutrient leaching. Biochar for environmental management: Science and technology 227-249.
Mandal, S., Shurin, J. B., Efroymson, R. A. and Mathews, T. J. (2018) Functional divergence in nitrogen uptake rates explains diversity-productivity relationship in microalgal communities. Ecosphere 9:e02228 doi:10.1002/ecs2.2228

Martín-Olmedo, P., Rees, R. M. (1999) Short-term N availability in response to dissolved-organic-carbon from poultry manure, alone or in combination with cellulose Biology and Fertility of Soils 29, 386-393.

McCarl, B. A., Peacocke, C., Chrisman, R., Kung, C.C. and Sands. R.D. (2009) Economics of biochar production, utilisation and GHG offsets, in Biochar for Environmental Management: Science and Technology, ed by Lehmann J. and Joseph S. Earthscan Publications Ltd., United Kingdom, pp. 341-358.

Mulvaney, R. L. (1996) Nitrogen Inorganic forms In DL Sparks (Ed.) Methods in Soil Analysis Part 3 Chemical Methods. SSSA Book Series No 5 SSSA, Madison, WI., 1123-1184.

Ojeniyi, S.O., Amusan, O. A. and Adekiya, A.O. (2013) Effect of Poultry Manure on Soil Physical Properties, Nutrient Uptake and Yield of Cocoyam (Xanthosomasaggitifolium) in Southwest Nigeria. American-Eurasian J. Agric.\& Environ. Sci. 13 (1), 121-125.

Page, A. L., Miller, R. H. and Keeney, D. R. (1982) Methods of Soil Analysis: Part 2, Chemical and Microbiological Properties. Agronomy Series No 9, 2nd ed. American Society of Agronomy, Madison, WI.

Pituello, C., Francioso, O., Simonetti, G., Pisi, A., Torreggiani, A., Berti, A. andMorari, F. (2014) Characterization of chemical-physical, structural and morphological properties of biochars from biowastes produced at different temperatures. $J$. Soils Sediments. 15, 792-804.

Revell, K. T., Maguire, R. O. and Agblevor, F. (2012) Influence of Poultry Litter Biochar on Soil Properties and Plant Growth. Soil Science, 177(6), 402-408.

Reynolds, W. D., Elrick, D. E. (1991) Determination of hydraulic conductivity using a tension infiltrometer. Soil. Sci. Soc. Am. J. 55, 633-639.

Schmidt, M. W., et al. (2011) Persistence of soil organic matter as an ecosystem property. Nature, 478, 49-56.

Sikder, S. and Joardar, J. C. (2018) Biochar production from poultry litter as management approach and effects on plant growth.International Journal of Egypt. J. Soil. Sci. Vol. 59, No. 1 (2019) 
Recycling of Organic Waste in Agriculture, pp 1-12. 10.1007/s40093-018-0227-5

Smolander, A. andKitunen, V. H. (2002) Soil microbial activities and characteristics of dissolved organic $\mathrm{C}$ and $\mathrm{N}$ in relation to tree species. Soil Biology \& Biogeochemistry, 34, 651-660.

Suliman, W., Harsh, J. B., Abu-Lail, N. I., Fortuna, A., Dallmeyer, I. and Garcia-Perez, M. (2016) Influence of feedstock source and pyrolysis temperature on biochar bulk and surface properties. Biomass and Bioenergy, 84, 37-48.

van den Berg, L. J., Shotbolt, L., Ashmore, M. R. (2012) Dissolved organic carbon (DOC) concentrations in UK soils and the influence of soil, vegetation type and seasonality. The Science of The Total Environment 427-428, 269-276.
Verheijen, F., Jeffery, S., Bastos, A. C., van der Velde, M. and Diafas, I. (2010) Biochar application to soils: A critical scientific review of effects on soil properties, processes and functions. Edition: EUR. Scientific and technical research series, 24099 Publisher: European Commission Publication Office, Luxembourg.

Zhang, J., Liu, J. and Liu, R. (2015) Effects of pyrolysis temperature and heating time on biochar obtained from the pyrolysis of straw and lignosulfonate. Bioresource Technology, 176, 288-291.

Zhang, Z., Zhu, Z., Shen, B. and Liu, L. (2019) Insights into Biochar and Hydrochar Production and Applications: A Review, Energy.doi: 10.1016/j. energy. 2019.01.035.

(Received:6/12/2018, accepted:30/1/2018)

\title{
سماد الدواجن وفحمه الحيوى كمسن وسماد للأراضى الرملية تحت ظروف المناطق الجافة \\ وجيه سيد محمد وعمرو أحمد همام

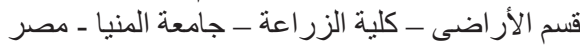

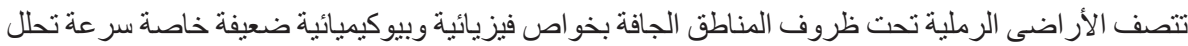

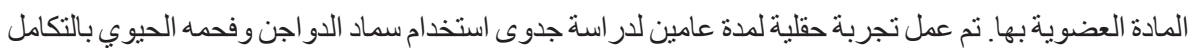

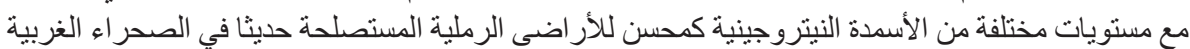

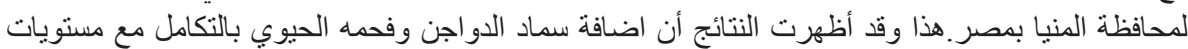

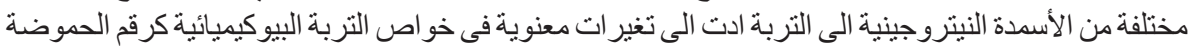

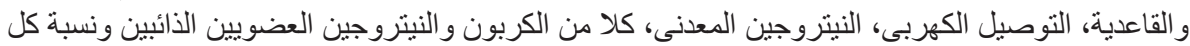

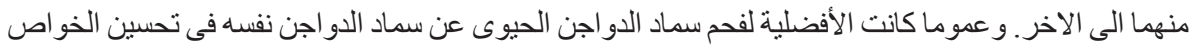

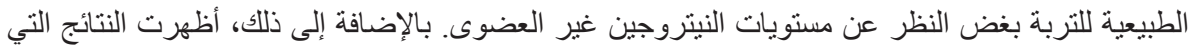

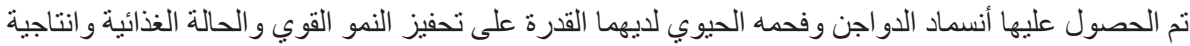

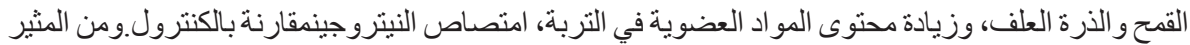

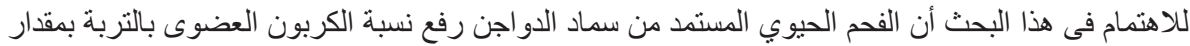

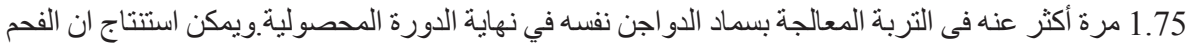

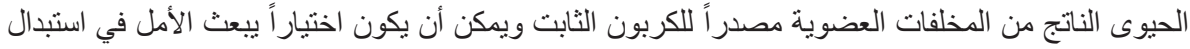

الأسمدة العضوية القابلة للتحلل بسهولة في الظروف القاحلة.
\end{abstract}

